\title{
Lost in translation? United States television news coverage of anthropogenic climate change, 1995-2004
}

\author{
Maxwell T. Boykoff
}

Received: 19 August 2005 / Accepted: 7 May 2007 / Published online: 24 July 2007

(C) Springer Science + Business Media B.V. 2007

\begin{abstract}
Eminent climate scientists have come to consensus that human influences are significant contributors to modern global climate change. This study examines coverage of anthropogenic climate change in United States (U.S.) network television news - $A B C$ World News Tonight, CBS Evening News and NBC Nightly News - and focuses on the application of the journalistic norm of 'balance' in coverage from 1995 through 2004. This study also examines CNN WorldView, CNN Wolf Blitzer Reports and CNN NewsNight as illustrations of cable news coverage. Through quantitative content analysis, results show that $70 \%$ of U.S. television news segments have provided 'balanced' coverage regarding anthropogenic contributions to climate change vis-à-vis natural radiative forcing, and there has been a significant difference between this television coverage and scientific consensus regarding anthropogenic climate change from 1996 through 2004. Thus, by way of the institutionalized journalistic norm of balanced reporting, United States television news coverage has perpetrated an informational bias by significantly diverging from the consensus view in climate science that humans contribute to climate change. Troubles in translating this consensus in climate science have led to the appearance of amplified uncertainty and debate, also then permeating public and policy discourse.
\end{abstract}

\section{Anthropogenic climate change}

Advances in climate science have shown that human activities chiefly influence modern global climate change (Houghton et al. 1996, 2001; McCarthy et al. 2001; Karl and Trenberth 2003). Time reconstructions of Northern Hemispheric mean temperatures demonstrate that the past 100 years have been the warmest since 1400 (Mann et al. 1998). Specifically, three quarters of atmospheric warming since 1850 - the beginning of the Industrial Revolution - has been attributed to anthropogenic sources (Crowley 2000).

M. T. Boykoff

James Martin 21st Century School Research Fellow, Environmental Change Institute,

Oxford University Centre for the Environment, Oxford, UK

M. T. Boykoff $(\square)$

University of Oxford, Dyson Perrins Building, South Parks Road, Oxford OX1 3QY, UK

e-mail: maxwell.boykoff@eci.ox.ac.uk 
Through climate research compiled over the last two decades through peer-reviewed and consensus-driven processes by the United Nations-sponsored Intergovernmental Panel on Climate Change (IPCC) (Argrawala 1998b), consensus has been reached that humans contribute significantly to changes in the climate. While separating and distinguishing anthropogenic climate forcing - or the 'enhanced greenhouse effect' - from natural variability has been a challenging task for the scientific community, investigations of climate change began as early as 1896 by Swedish Nobel prize-winning physicist Svante Arrhenius (Fleming 1998). Since then, the accumulated evidence through decades of research has found and reinforced that human activities play a significant role in climate change (Flannery 2006; Weart 2003).

While it generally can be a challenge to characterize and delineate 'consensus' in broadly construed scientific communities, the unique collaboration of top scientists from around the world through the IPCC presents such an opportunity in climate science (Argrawala 1998a; Karl and Trenberth 2003). The IPCC has been "regarded as the single most authoritative source of information on climate change and its potential impacts on environment and society" (Edwards and Schneider 1997, pp. 1-2). Findings by the IPCC on anthropogenic climate change are also supported by numerous national science academies. For example, a June 2005 'Joint Science Academies' Statement' declared that "it is likely that most of the warming in recent decades can be attributed to human activities" (Joint Science Academies' Statement 2005, p. 1). This statement was signed by eleven national science academies: Brazil, Canada, China, France, Germany, India, Italy, Japan, Russia, the United Kingdom and the United States. Moreover, in December 2003 another top U.S. domestic scientific body - the American Geophysical Union - released a 'Position Statement on Human Impacts on Climate', which read, "Human activities are increasingly altering the Earth's climate. These effects add to natural influences that have been present over Earth's history. Scientific evidence strongly indicates that natural influences cannot explain the rapid increase in global near-surface temperatures observed during the second half of the 20th century" (Showstack 2003, p. 574). After the release of this statement, AGU President Robert Dickenson responded to a question about whether all scientific papers agree with this 2003 AGU position statement. He commented, "We are not saying you can't come up with other conclusions by finding one or two papers somewhere. We are saying [that] if you look at [the peer-reviewed literature] overall and you synthesize the evidence, the statement we are putting [out] here is the consensus view of where we are now" (Showstack 2003, p. 574). In fact, all statements on anthropogenic climate change from major U.S. scientific bodies have been consistent with these assertions (Oreskes 2004). Furthermore, a 2004 study found that of 928 journal articles on global climate change that were published in peer-reviewed scientific journals between 1993 and 2003, none refuted the consensus position that humans contribute to climate change (Oreskes 2004). Thus, IPCC findings and reports effectively articulate a dominant and legitimate global environmental management discourse (Adger et al. 2001). Overall, it is this robust climate science that is relevant to and informs national and international policy discourse and action as well as public understanding of anthropogenic climate change.

\section{Science, media and the public}

Meanwhile, research has found that the general public in the U.S. learns much of what it knows about science and policy from the mass media (Nelkin 1987; Wilson 1995). Also, research has found that television is the primary source of that information (Pew 2003; NSF 
2004). In discussing news media influence, Bennett has asserted, "Few things are as much a part of our lives as the news...it has become a sort of instant historical record of the pace, progress, problems, and hopes of society" (Bennett 2002, p. 10). Thus, news media are powerful vehicles for communication of climate science: they have the potential to effectively communicate anthropogenic climate science, as well as the potential to misrepresent, misunderstand, distort and misinform to varying degrees the climate science they cover (e.g. Henderson-Sellers 1998). This has critical implications for policy. Boehmer-Christiansen has asserted, "The environmental policy problem facing societies is twofold: (1) how to ensure that useful knowledge informs policy without being misused and distorted; and (2) how to respond to this knowledge in the context of existing patterns of interests, perceptions and commitments" (1994, p. 140).

Professionalized journalism standards and norms have developed over time as efforts to minimize potential pitfalls in reporting (Starr 2004). Through interactions with complex and multi-level sociopolitical, ethical and economic factors and pressures (Bennett 2002), journalistic norms such as objectivity, balance, fairness and accuracy have shaped what becomes news, as well as how news is portrayed. Focusing on 'balanced reporting', media researchers have asserted that it often functions as "a surrogate for validity checks" because "the typical journalist, even one trained as a science writer, has neither the time nor the expertise to check the validity of claims herself" (Dunwoody and Peters 1992, p. 210). Furthermore, scholars and practitioners have considered the journalistic norm of balance to be a vital tool to carry out neutral or 'objective' reporting, by providing "both sides in any significant dispute with roughly equal attention” (Entman 1989, p. 30).

\section{Television coverage of climate change}

This study examined the journalistic norm of balanced reporting when applied to coverage of anthropogenic climate change, and focused on U.S. network television news coverage. The U.S. - top emitter of greenhouse gases (GHGs) producing approximately $25 \%$ of GHGs worldwide with 4\% of the world's population (McCarthy et al. 2001) - is at the center of this international issue; hence, analyses of U.S. television news coverage of climate change are important. Building from the science on anthropogenic climate change, this study incorporated assessments from salient climate research that has critically informed a global environmental management discourse regarding anthropogenic climate change (see, for example, Mann et al. 1998; Crowley 2000; Falkowski et al. 2000; Karl and Trenberth 2003). The research examined whether the balance norm has helped or hindered accurate translations on the science of anthropogenic climate change. It interrogated the following hypothesis: through adherence to the journalistic norm of 'balanced reporting', television news coverage of anthropogenic climate change actually perpetrates an informational bias by significantly diverging from the consensus view in climate science that human activities contribute to climate change.

\subsection{Methods}

The primary data set for the study was composed of television news segments from a population of U.S. network nightly news broadcasts from 1995 through 2004: ABC World News Tonight, CBS Evening News and NBC Nightly News. A secondary data set was compiled from the nightly news broadcasts of CNN WorldView, CNN Wolf Blitzer Reports and CNN NewsNight. The overall sample of news segments was composed through a 
Fig. 1 United States network television coverage of anthropogenic climate change, 19952004; $n=213$. This figure shows the number of network television evening news segments covering anthropogenic climate change from 1995 to 2004 . The programs are the ABC World News Tonight, CBS News and NBC Nightly News

\section{United States Network Television Coverage of Anthropogenic Climate Change}

1995-2004

$n=213$

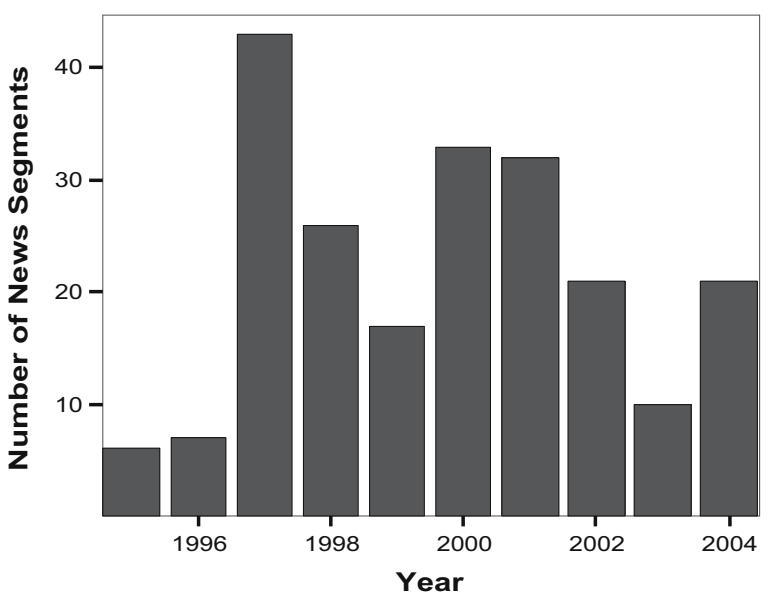

search of the keywords 'global warming', 'climate change' and 'global climate change'. Similar search terms have been used in related studies (Oreskes 2004; Boykoff and Boykoff 2004). The data were accessed and compiled through the Vanderbilt University Television News Archive. ${ }^{1}$ The network news programs on $A B C, C B S$ and $N B C$ were selected as representative of television news coverage of anthropogenic climate change because these outlets are by far the most watched sources of television news. In 2004, an average of 28.8 million viewers watched the three network evening newscasts each evening. The $N B C$ Nightly News generates 11.2 million viewers, while ABC World News Tonight attracts 9.9 million and CBS Evening News garners 7.7 million. Trends in cable news viewer sizes show increases, however audiences are still much less significant when compared to the network evening news broadcast audience. In 2004, the number of viewers of network evening news broadcasts was approximately 11 times greater than that of cable viewers. 2.6 million viewers watched cable evening newscasts (a $6 \%$ increase from 2003), where $F O X$ captured $55 \%$ of the market (1.47 million in primetime), $C N N$ held $30 \%(850,000$ in primetime) and $M S N B C$ controlled 15\% (341,000 in primetime) (Project for Excellence in Journalism 2005).

Using the keyword selection parameters, 213 news segments were broadcast on the $A B C, C B S$ and $N B C$ evening news programs from 1995 through 2004 (Fig. 1). In this grouping of network television news segments, the population consisted of $31 \%$ from $A B C$ World News Tonight, 36\% from CBS Evening News, and 33\% from NBC Nightly News. The sample from this population contained 115 news clips $(n=115)$, which was $54 \%$ of the population. This sample was compiled in a two-step process: First, a pilot study was conducted with a news clip randomly selected from each year of the study; second, a

\footnotetext{
${ }^{1}$ FOX News segments and archives were not available for analysis. This shaped the decision to select and examine CNN WorldView, CNN Wolf Blitzer Reports and CNN NewsNight segments for analysis of a cable news source through the Vanderbilt Television News Archives.
} 
sample was compiled through selection of every other news clip, arranged chronologically. The sample was assembled by systematically opting in from a random starting point in January 1995. In this sample, 36\% then came from ABC World News Tonight, 31\% from CBS Evening News, and 33\% from NBC Nightly News. Also, approximately 30\% of the segments were reports from the news anchors (called 'reader reports') while the remaining pieces were produced and edited news packages. The secondary sample set of news segments from CNN WorldView, CNN Wolf Blitzer Reports and CNN NewsNight was compiled through the selection of every other news clip as arranged chronologically, and beginning also from a random starting point in January of 1995. There were 55 news segments from 1995 to 2004 , and the sample size comprised $51 \%$ from this period. The randomized research design across both data sets meant that the samples were larger in years with more television news coverage of anthropogenic climate change.

Sampling began in 1995 because consensus in the climate science community regarding anthropogenic climate change emerged clearly and cohesively in this year. Late in that year the full plenary of the IPCC released the 11,000 word Second Assessment Report. This document stated, "The balance of evidence suggests that there is a discernible human influence on the global climate" (Houghton et al. 1996, p. 22). Also, in March and April of 1995 the first Conference of Parties (COP) talks from the United Nations Framework Convention on Climate Change (UNFCCC) took place in Berlin, Germany. It was here that the 'Berlin Mandate' was constructed, calling on parties to the UNFCCC to develop a protocol to require anthropogenic greenhouse gas emissions reductions, with the first phase focusing on industrialized countries. ${ }^{2}$

As discussed above, this consensus in climate science communities regarding human contributions to climate change has been re-confirmed and thus strengthened numerous times in the years that followed. Also, the IPCC's Third Assessment Report in 2001 concluded that "most of the warming observed over the last 50 years is attributable to human activities" (Houghton et al. 2001, p. 10).

The stated hypothesis was interrogated through content analysis of the news segments. The coding for the content analysis measure followed on previous investigations of U.S. newspaper coverage of anthropogenic climate change (Boykoff and Boykoff 2004). This measure assigned different codes for segments that (1) presented the viewpoint that anthropogenic global warming (distinct from natural variations) accounts for all climate changes, (2) presented multiple viewpoints, but emphasized that anthropogenic contributions, distinct from yet still in combination with natural variation, significantly contribute to climate changes (most accurately communicating the dominant view from climate science), (3) gave 'a balanced account' surrounding existence and non-existence of anthropogenic climate change, and (4) presented multiple viewpoints but emphasized the claim that anthropogenic component contributes negligently to changes in the climate. The coding was determined not by tallying up comments or frequencies of words or phrases. Rather, coders undertook a critical discourse analytic approach, where importance was placed on labeling of those quoted, terminology, framing techniques, salience of elements in the text, tone, and relationships between clusters of messages. 'Balance' was thus determined to be coverage that provided roughly equal attention and emphasis to competing viewpoints on anthropogenic climate change, however not necessarily equal time and space (Entman 1989; Dunwoody and Peters 1992). The content analysis measure underwent validity and reliability pilot testing for television news coverage and achieved an inter-coder reliability rate of

\footnotetext{
${ }^{2}$ This protocol later became the 'Kyoto Protocol', negotiated at COP3 in Kyoto, Japan in 1997.
} 


\title{
U.S. Network Television News Coverage of Anthropogenic Climate Change
}

1995-2004; $\mathrm{n}=115$

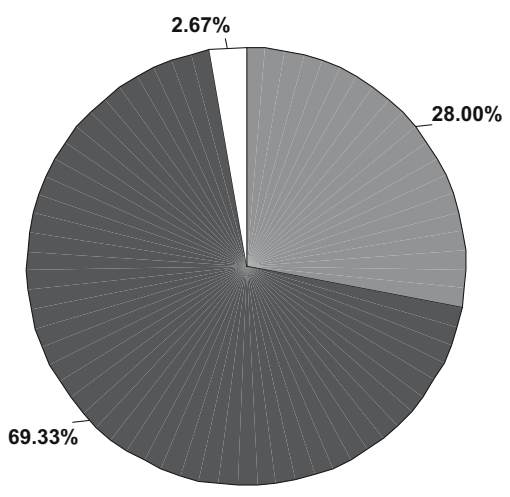

\author{
Coverage of Anthropogenic Contributions \\ $\square$ anthropogenic contribution depicted as significant \\ balanced accounts of anthropogenic contributions to warming \\ anthropogenic contribution depicted as negligent
}

Pies show percents

Fig. 2 U. S. network television news coverage of anthropogenic climate change, 1995-2004; $n=15$. This figure shows the range of network television evening news coverage regarding anthropogenic contributions to climate change vis-à-vis natural radiative forcing. Coverage is from $\mathrm{ABC}$ World News Tonight, the CBS Evening News and the NBC Nightly News

$93.75 \%{ }^{3}$ This pre-testing accounted for spuriousness while also integrating past knowledge and familiarity with various facets of climate change science, policy and news coverage.

\subsection{Results}

Descriptive statistics run on the sample across all years show that $69 \%$ of network evening news segments provided 'balanced' coverage regarding anthropogenic climate change vis-à-vis natural variation, while $28 \%$ of the news clips depicted the role of anthropogenic contributions as significant and distinct from natural variations, and $3 \%$ of the sample depicted anthropogenic climate change as a negligent factor in overall changes in the climate, and global warming (Fig. 2).

Coverage of anthropogenic climate change was then broken down by year from 1995 through 2004, along with an analysis of the significance of differences between television news coverage of anthropogenic climate change and consensus in climate science regarding anthropogenic climate change (Table 1). The latter was undertaken through a comparison of ratios of coverage each year. The null hypothesis was that the television coverage reflected the scientific perspective on anthropogenic climate change in each year $\left(\mathrm{H}_{0}: \pi_{1}=\pi_{2}\right)$, and the alternative hypothesis was that the means were significantly different $\left(\mathrm{H}_{\mathrm{a}}: \pi_{1} \neq \pi_{2}\right)$. The $\mathrm{Z}$-score significance test is similar to a $t$-test $(z \geq 1.96 \rightarrow p=0.05 ; z \geq 2.575 \rightarrow p=0.01 ; z \geq$ $3.29 \rightarrow p=0.001)$ :

$$
z=\frac{\left(\pi_{1}-\pi_{2}\right)-0}{\widetilde{O}_{\pi 1-\pi 2}^{\prime}} \quad \text { and } \quad \widetilde{O}_{\pi 1-\pi 2}^{\prime}=\sqrt{\pi^{\wedge}\left(1-\pi^{\wedge}\right)\left(1 / n_{1}+1 / n_{2}\right)}
$$

where $\pi^{\wedge}=$ pooled estimate based on whole sample.

\footnotetext{
${ }^{3}$ This intercoder reliability was established through independent data analysis in coordination with colleague Jules M. Boykoff, Assistant Professor of Political Science at Pacific University. Jules Boykoff co-authored a previous study of U.S. newspaper coverage of anthropogenic climate change. A randomly selected set of television news segments were independently analyzed according to the established content analysis measure.
} 
Table 1 U.S. network television news discourse and scientific discourse regarding anthropogenic climate change: by year, 1995-2004; $n=115$

\begin{tabular}{|c|c|c|c|c|}
\hline Year & $\begin{array}{l}\text { Coverage of climate } \\
\text { change science that } \\
\text { depicted significant } \\
\text { human contributions (\%) }\end{array}$ & $\begin{array}{l}\text { 'Balanced' } \\
\text { coverage of } \\
\text { anthropogenic } \\
\text { climate change } \\
(\%)\end{array}$ & $\begin{array}{l}\text { Coverage of climate } \\
\text { change science that } \\
\text { depicted negligent } \\
\text { human contributions } \\
(\%)\end{array}$ & $\begin{array}{l}\text { Was the difference between } \\
\text { network television news } \\
\text { coverage and climate science } \\
\text { consensus statistically } \\
\text { significant? }\end{array}$ \\
\hline 1995 & 33 & 66 & 0 & No \\
\hline 1996 & 40 & 40 & 20 & Yes* \\
\hline 1997 & 22 & 72 & 6 & Yes*** \\
\hline 1998 & 17 & 83 & 0 & Yes* \\
\hline 1999 & 25 & 75 & 0 & Yes* \\
\hline 2000 & 18 & 82 & 0 & Yes*** \\
\hline 2001 & 42 & 58 & 0 & Yes** \\
\hline 2002 & 20 & 80 & 0 & Yes** \\
\hline 2003 & 40 & 60 & 0 & Yes* \\
\hline 2004 & 33 & 66 & 0 & Yes* \\
\hline Total & 27 & 70 & 3 & Yes*** \\
\hline
\end{tabular}

The numbers represent the percentages of coverage in each year. The first column represents the coverage of significant human contributions to climate change that accurately reflects climate science consensus. The significance of the divergence of the U.S. network television news coverage from the climate science consensus regarding anthropogenic climate change was determined through $z$-scores that compare proportions. The $z$-scores per year were as follows: $1995=1.71 ; 1996=1.99 ; 1997=4.19 ; 1998=1.99$; $1999=2.23 ; 2000=4.01 ; 2001=2.99 ; 2002=2.96 ; 2003=1.99 ; 2004=2.42$.

$* p<.05$

$* * p<.01$

$* * * p<.001$

Following on these findings, this study then examined coverage of anthropogenic climate change during this same time period on CNN WorldView, CNN Wolf Blitzer Reports and CNN NewsNight. Furthermore, analyses examined each network television broadcast through the study period to determine if there were any exceptions to the overall trends revealed. Including the $C N N$ segments with the previous data set, the total sample was 143 news clips, and approximately $29 \%, 25 \%, 27 \%$, and $20 \%$ came from $A B C, C B S, N B C$ and $C N N$ respectively (Table 2). These analyses showed that $70 \%$ of U.S. television news segments across the four networks have provided 'balanced' coverage regarding anthropogenic contributions to climate change vis-à-vis natural radiative forcing over the study period of 1995 through 2004. On each network, analyses demonstrated that coverage was significantly different from the consensus view in the climate science community regarding human contributions to climate change.

\section{Attribution of informational bias}

A 2005 U.S. public opinion survey found television news to be one of the most trusted information sources on environmental issues (Yale 2005). However, nightly television news coverage of environmental issues - and more specifically climate change - has waned. According to the Tyndall Report, $A B C, C B S$ and $N B C$ television evening news broadcasts have carried declining coverage of environmental issues since the late 1980s (Tyndall Report 2006). Andrew Tyndall commented, "attempts to cover global warming per se amount to occasional discretionary features on light news days" (Bruggers 2006). 
Table 2 U.S. network television and CNN news discourse regarding anthropogenic climate change: 1995$2004 ; n=143$

\begin{tabular}{lllll}
\hline Network & $\begin{array}{l}\text { Coverage of climate } \\
\text { change science that } \\
\text { depicted significant } \\
\text { human contributions } \\
(\%)\end{array}$ & $\begin{array}{l}\text { 'Balanced' } \\
\text { coverage of } \\
\text { anthropogenic } \\
\text { climate change } \\
(\%)\end{array}$ & $\begin{array}{l}\text { Coverage of climate } \\
\text { change science that } \\
\text { depicted negligent } \\
\text { human contributions } \\
(\%)\end{array}$ & $\begin{array}{l}\text { Was the difference between } \\
\text { network television news } \\
\text { coverage and climate } \\
\text { science consensus } \\
\text { statistically significant? }\end{array}$ \\
\hline ABC & 40 & 60 & 0 & Yes*** \\
CBS & 14 & 86 & 0 & Yes*** \\
NBC & 34 & 58 & 8 & Yes*** \\
CNN & 29 & 71 & 0 & Yes*** \\
Total & 28 & 70 & 2 & Yes***
\end{tabular}

The numbers represent the percentages of coverage from 1995 to 2004 . The television news programs examined were ABC World News Tonight, CBS Evening News, NBC Nightly News, CNN WorldView, CNN Wolf Blitzer Reports and CNN NewsNight. The first column is the coverage of significant human contributions to climate change that is reasoned to accurately reflect climate science consensus. The significance of the divergence of the U.S. television news coverage from the climate science consensus regarding anthropogenic climate change was determined through $z$-scores that compare proportions. The $z$-scores per network were as follows: $\mathrm{ABC}=3.97 ; \mathrm{CBS}=6.89 ; \mathrm{NBC}=4.37 ; \mathrm{CNN}=3.97$.

$* * * p<.001$

In this milieu, the findings here show that through the journalistic norm of 'balance', U.S. television news coverage has been deficient in anthropogenic climate science reporting. The institutionalized and professional journalistic practice of balanced reporting has served to amplify a minority view that human's role in climate change is debated or negligent, and has concurrently engendered an appearance of increased uncertainty regarding anthropogenic climate science. This 'policy-relevant' information, in turn, enters a highly contested arena when it permeates climate policy discourse and is used in policy decision-making (McCright and Dunlap 2003). ${ }^{4}$ When mass media coverage distorts rather than clarifies scientific understanding of anthropogenic climate change, it can greatly impact how U.S. federal policy actors both perceive and approach actions and remedies (Trumbo 1996).

Questions of humans' role in changing the climate contribute to the destabilization of key interests and stakeholders - from carbon-based energy industry to fossil-fuel consumers. Consequently, anthropogenic climate change has remained a discursive

\footnotetext{
${ }^{4}$ This has manifested collectively as well as individually. For instance, on July 19, 2006, the U.S. House Energy and Commerce Subcommittee on Oversight and Investigations held a hearing entitled, "Questions Surrounding the 'Hockey Stick' Temperature Studies: Implications for Climate Change Assessments". At this hearing, some members of Congress used the hearing as a platform to call into question more general climate science credibility regarding anthropogenic climate change. Representative Michael Burgess said, "it is false to presume that a consensus today exists today or that human activity has been proven to cause global warming...and that is the crux of this hearing". Chairman Joe Barton added, "my problem is that everybody seems to think that [anthropogenic climate change] is automatically a given and we shouldn't even debate the possibility of it or we probably shouldn't debate the causes of it and I think that's wrong" (Harris 2006). Furthermore, James Inhofe - Chair of the U.S. Senate Environment and Public Works committee - has said on the Senate floor, "could it be that man-made global warming is the greatest hoax ever perpetrated on the American people? It sure sounds like it" (Inhofe 2003). In July of 2006, Inhofe referred to the consistent claims from climate science that humans contribute to climate change as "the big lie...you say something over and over again, and people will believe it, and that's their strategy". In this interview with the Tulsa World - from Inhofe's home state of Oklahoma - the article also states, "He blames the media for handing over an unfair amount of air time and coverage to the side that pushes the claim that links man to climate change" (Myers 2006).
} 
battlefield through the present time (Pielke and Sarewitz 2002). This has been illustrated many times within government as well as the private carbon-based energy sector. For instance, in 2005 it was revealed that White House Council on Environmental Quality official Philip Cooney overrode established peer-review processes and edited key U.S. government climate reports in 2002 and 2003 to tone down links between anthropogenic GHG emissions and climate change (Revkin 2005). Moreover, in July of 2006, ABC News revealed that the Intermountain Rural Electric Association paid $\$ 100,000$ to climate contrarian Patrick Michaels to downplay human's role in climate change and confuse public understanding of anthropogenic climate change (Sandell and Blakemore 2006). Additionally, on June 26, 2006 President George W. Bush said, "I have said consistently that global warming is a serious problem...there is a debate over whether it is man-made or naturally caused". 5

Television news reporting has thus struggled to accurately communicate anthropogenic climate science. While some posit that media representational practices regarding anthropogenic climate change are coming into greater alignment with the science, this study finds that through the end of the study period of 2004 there remained a significant difference between climate science and television press accounts. In sum, this research is another effort to elucidate the pivotal role of U.S. mass media - in this case television news in shaping ongoing science and policy action through reporting on anthropogenic global climate change. This issue is acutely important, as U.S. television news reports on issues such as the upcoming IPCC Fourth Assessment Report - to be released in 2007 - will be influential in public and policy-maker understanding of the most recent climate science. While 1995-2004 may be viewed as the 'lost decade' of U.S. television news coverage of anthropogenic climate change, there remain opportunities for improvements on the horizon.

Acknowledgements I thank J.M. Boykoff, D. Riebau, D.E. Goodman, M.E. Loik, M.K. Goodman, M.D.M. Boykoff, M. Dupuis, D. Banghart and D. Takagi. I also wish to thank my four anonymous reviewers for the tremendously insightful and useful comments and suggestions. This research was presented at the 2006 Royal Geographical Society Institute of British Geographers Conference, and was partially supported by a University of California Science, Technology, Engineering, Policy and Society (STEPS) Institute for Innovation research grant.

\section{References}

Adger WN, Benjaminsen TA, Brown K, Svarstad H (2001) Advancing a political ecology of global environmental discourses. Dev Change 32:681-715

Argrawala S (1998a) Context and early origins of the intergovernmental panel on climate change. Clim Change 39:605-620

Argrawala S (1998b) Structural and process history of the intergovernmental panel on climate change. Clim Change 39:621-642

Bennett WL (2002) News: the politics of illusion. Longman, New York.

\footnotetext{
${ }^{5}$ President George W. Bush has made a number of inconsistent statements on this issue over time. For instance, on his way to the G-8 Summit in 2005, Bush stated, "I recognize that the surface of the Earth is warmer and that an increase in greenhouse gases caused by humans is contributing to the problem" (Moran 2005). Many have argued that these inconsistencies contribute to raising the specter of uncertainty and confusion in the U.S. public regarding anthropogenic climate change.
} 
Boehmer-Christiansen S (1994) Global climate protection policy: the limits of scientific advice part 1. Glob Environ Change 4:140-159

Boykoff MT, Boykoff JM (2004) Bias as balance: global warming and the U.S. Prestige Press. Glob Environ Change 14:125-136

Bruggers J (2006) Watchdog earth: for greens, the T.V. News Blues, July 31, available at http://www.courierjournal.com/blogs/bruggers/2006_07_01_archive.html

Crowley TJ (2000) Causes of climate change over the past 1000 years. Science 289:270-277

Dunwoody S, Peters HP (1992) Mass media coverage of technological and environmental risks. Public Underst Sci 1:199-230

Edwards PN, Schneider SH (1997) The 1995 IPCC report: broad consensus of "scientific cleansing? Ecofables/Ecoscience 1:3-9

Entman R (1989) Democracy without citizens: media and the decay of American politics. Oxford University Press, Oxford, UK

Falkowski PR, Scholes RJ, Boyle E, Canadell J, Canfield D, Elser J, Gruber N, Hibbard K, Hogberg P, Linder S, Mackenzie FT, Moore B III, Pederson T, Rosenthal Y, Seitzinger S, Smetacek V, Steffen W (2000) The global carbon cycle: a test of our knowledge of Earth as a system. Science 290:291-296

Flannery T (2006) The weathermakers: how man is changing the climate and what it means for life on earth. Atlantic Monthly Press, New York

Fleming R (1998) Historical perspectives on climate change. Oxford University Press, Oxford, UK

Harris R (2006) Global warming a hot topic in congressional hearing. National Public Radio, July 20, available at http://www.npr.org/templates/story/story.php?storyId=5569901

Henderson-Sellers A (1998) Climate whispers: media communication about climate change. Clim Change 40:421-456

Houghton JT, Meira Filho LG, Callander BA, Harris N, Kattenberg A, Maskell K (eds) (1996) Climate change 1995: the science of climate change - contribution of working group I to the second assessment report of the intergovernmental panel on climate change. Cambridge University Press, Cambridge, UK

Houghton JT, Ding Y, Griggs DJ, Noguer M, van der Linden PJ, Dai X, Maskell K, Johnson CA (eds) (2001) Climate change 2001: the scientific basis - contribution of working group I to the third assessment report of the intergovernmental panel on climate change. Cambridge University Press, Cambridge, UK

Inhofe J (2003) The science of climate change. Senate Floor Statement. Chairman, Committee on Environment and Public Works, US Senate, July 28

Joint Science Academies' Statement: Global Response to Climate Change (2005) available at http://www. academie-sciences.fr/actualites/textes/G8_gb.pdf\#search=\%22Joint $\% 20$ Science $\% 20$ Academies $\%$ E2 $\%$ $80 \% 99 \% 20$ Statement $\% 3$ A $\% 20$ Global $\% 20$ Response $\% 20$ to $\% 20$ Climate $\% 20$ Change $\% 22$

Karl TR, Trenberth KE (2003) Modern global climate change. Science 302:1719-1723

Mann ME, Bradley RS, Hughes MK (1998) Global-scale temperature patterns and climate forcing over the past six centuries. Nature 344:779-787

McCarthy JJ, Canziani OF, Leary NA, Dokken DJ, White KS (eds) (2001) Climate change 2001: impacts, adaptation and vulnerability - contribution of working group II to the IPCC third assessment report. Cambridge University Press, Cambridge, UK

McCright A, Dunlap R (2003) Defeating Kyoto: the conservative movement's impact on U.S. climate change policy. Soc Probl 50:348-373

Moran T (2005) At the summit meeting of the G-8. ABC World News Tonight, 6 July

Myers J (2006) Heat wave has senator sticking to beliefs. Tulsa World, 22 July

Nelkin D (1987) Selling science: how the press covers science and technology. Freeman, New York

NSF Science and Engineering Indicators 2004 (2004) available at http://www.nsf.gov/sbe/srs/seind04/start. htm

Oreskes N (2004) The scientific consensus on climate change. Science 306:1686

Pew Research Center for People and the Press Summary Report (2003) October 21, available at http:// people-press.org/

Pielke RA Jr, Sarewitz D (2002) Wanted: scientific leadership on climate. Issues Sci Technol 1:27-30

Project for Excellence in Journalism (2005) The State of the News Media 2004, available at http://www. stateofthenewsmedia.org

Revkin AC (2005) Bush aide edited climate reports. New York Times, 8 June, A1

Sandell C, Blakemore B (2006) Making money by feeding confusion over global warming. ABC News, 27 July

Showstack R (2003) Climate change statement highlights human influence. Eos 84:574

Starr P (2004) The creation of the media: political origins of modern communications. Basic Books, New York 
Trumbo C (1996) Constructing climate change: claims and frames in US news coverage of an environmental issue. Public Underst Sci 5:269-283

Tyndall Report (2006) Tyndall Report 2005 Year in Review, available at http://www.tyndallreport.com/ yearinreview.php3

Weart SR (2003) The discovery of global warming. Harvard University Press, Cambridge, Massachusetts Wilson KM (1995) Mass media as sources of global warming knowledge. Mass Commun Review 22:75-89

Yale University School of Forestry and Environmental Studies (2005) available at http://www.yale.edu/ environcenter 